KAMIL JEZIERSKI ๑ https://orcid: 0000-0001-6935-4710

Instytut Psychologii, Akademia Ignatianum w Krakowie Institute of Psychology, Jesuit University Ignatianum in Krakow e-mail: kamil.jezierski@ignatianum.edu.pl

\title{
Specyfika rozwojowa struktury pamięci dzieciństwa w biegu dorosłego życia - wyniki badań narracyjnych
}

\author{
Developmental Specificity of Childhood Memory Structure \\ across the Adult Lifespan - Results of Narrative Research
}

\begin{abstract}
Theories of autobiographical memory and narrative identity allow us to assume that childhood memory is represented in the mind of an adult person as a comprehensive period with its own unique characteristics that is subjected to changes during the lifespan. Based on the concept of the global coherence of life history, it was assumed that in later periods of life, childhood memories will be more elaborate and thus cognitively more accessible as well as organized temporally and logically in a more coherent story.

The use of narrative interview revealed differences between early, middle and late adulthood in the way the childhood memories are organized, as well as in the age-independent characteristics of the perceived childhood. The obtained results suggest that in late adulthood, childhood is recalled more extensively and more memories are logically organized, which is attributed to greater attention to the past resulting from the task of life summary. Regardless of the age of the respondents, less than half of the memories related logically to each other, with most of the text consisting of separate scenes not located in time. These findings raised the issue of the specificity of childhood memory and the universality of global coherence of life stories.
\end{abstract}

Keywords: lifespan development, autobiographical memory, narrative identity, life story, childhood image

Słowa kluczowe: rozwój w biegu życia, pamięć autobiograficzna, tożsamość narracyjna, historia życia, obraz dzieciństwa

\section{WPROWADZENIE}

\section{Dzieciństwo jako zmieniający się konstrukt dorosłych}

Tematyka dzieciństwa była i nadal jest szeroko eksplorowana na gruncie nauk społecznych oraz humanistycznych. Analizy historyczne pomogły ukazać ten okres jako wytwór dorosłych, który może podlegać istotnym zmianom w czasie (Kehily, 2008). Philippe Ariès (1995) twierdzi, że w średniowiecznej Europie dzieciństwo trakto- wano jako etap przejściowy i mało istotny, Maria Szczepska-Pustkowska (2009) stawia nawet prowokacyjną tezę, że w XVII wieku dzieciństwo zostało nie tyle odkryte, co wynalezione. Współczesny obraz dzieciństwa jako istotnego lub nawet kluczowego okresu w życiu człowieka został ukształtowany przy aktywnym udziale psychologii rozwojowej i nauk o wychowaniu (Kessen, 1979; Kielar-Turska, 2000), a koncentracja na rozwoju człowieka we wczesnych etapach życia przyczyniła się do uznania XX wieku stuleciem dziecka (Koops, 2003). Do- 
strzeżenie, że dzieciństwo jest ewoluującym konstruktem dorosłych, implikuje niezwykle interesujące pytanie o sposób, w jaki ten okres prezentuje się i zmienia w prywatnej wiedzy człowieka dorosłego.

Bazując na założeniach konstruktywizmu poznawczego (Piaget, 1926/2011; Bruner, 1991), można podejrzewać, że reprezentacja umysłowa dzieciństwa zmienia się wraz z rozwojem. Koncepcje pamięci autobiograficznej i tożsamości narracyjnej pokazują, że osobista przeszłość jest aktywnie rekonstruowana przez człowieka w odniesieniu do aktualnego kontekstu sytuacyjnego i osobowego, a szczególnie obrazu ,ja" oraz celów życiowych (Baddeley, Singer, 2007; McAdams, McLean, 2013). Co więcej, koncepcje te zakładają, że wspomnienia pozostają spójne z wiedzą autobiograficzną zawierającą reprezentację większych części autobiografii (Conway, Singer, Tagini, 2004). Współcześnie przyjmuje się założenie, że pamięć własnej przeszłości nie jest jedynie kolekcją zapamiętanych doświadczeń, tworzy ją dopiero ułożenie ich w strukturę narracyjną odnoszącą się do poczucia tożsamości jednostki (Fivush, Bauer, 2010). Pamięć autobiograficzna rozwija się w dzieciństwie w kolejności odpowiadającej jej hierarchicznej strukturze. Najpierw dziecko w wieku przedszkolnym w dialogu z opiekunem uczy się układać pojedyncze doświadczenia w sensowny epizod narracyjny. Następnie zbliżone treściowo i powtarzające się doświadczenia tworzą uogólnione wspomnienia, które później wchodzą w skład reprezentacji okresów lub obszarów życia, aż wreszcie w okresie adolescencji pojawia się nadrzędny wobec nich schemat całej autobiografii (Bluck, Habermas, 2001; Fivush, 2011). Od czasu wkroczenia w dorosłość poszczególnym wspomnieniom nadawane jest osobiste znaczenie $\mathrm{i}$ wartościowanie $\mathrm{z}$ aktualnego punktu widzenia człowieka (Bartosz, 2004; Dryll, 2008). Prawdopodobnie również w tym okresie powstaje dojrzała reprezentacja dzieciństwa.

\section{Pamięć okresów życia}

Pamięci autobiograficznej człowieka dorosłego nie można sprowadzić do sumy wspomnień, gdyż istotne jest też ułożenie poszczególnych doświadczeń w spójną całość. W obszarze psychologii narracyjnej popularność zyskały konstrukty tożsamości narracyjnej jako uwewnętrznionej historii życia (McAdams, McLean, 2013) oraz wspomnień definiujących własną osobę (ang. self-defining memories) (Baddeley, Singer, 2007). Bardzo wyraźnie zaznacza się w nich aspekt rozwojowy poprzez uznanie, że ważne doświadczenia osobiste są konstruowane tak, aby pasowały do globalnego wzorca historii życia i osobistego systemu znaczeń osoby, który ma potencjał zmiany pod wpływem kolejnych doświadczeń i zadań życiowych (Dryll, 2008).

Mimo widocznego progresu badań nad autobiografiami zaskakująco mało uwagi poświęcano tematyce pamięci poszczególnych okresów życia. Dzieciństwo jest niewątpliwie wyjątkowym etapem rozwojowym i oczywiście można wymieniać liczne powody naukowego zajmowania się jego postrzeganiem w biegu dorosłego życia. Przykładowo sposób rozumienia doświadczeń z wczesnych lat życia odgrywa istotną rolę $\mathrm{w}$ postrzeganiu siebie i kierowaniu własnym rozwojem (Pietrasiński, 1988; Staudinger, 2001). W psychodynamicznym podejściu do psychoterapii poszukuje się źródeł aktualnych problemów w doświadczeniach dziecięcych (Gabbard, 2011). Mimo tego brakuje badań ukazujących pamięć okresu dzieciństwa jako osobnego i całościowego konstruktu (Manczak i in., 2016). W psychologii naukowej rozwijano wiedzę ludzi o własnym dzieciństwie, przede wszystkim zajmując się pojedynczymi wspomnieniami w ramach badań nad pamięcią autobiograficzną lub rozumieniem całości historii życia w podejściu narracyjnym. Ograniczenie się do dwóch poziomów pamięci autobiograficznej: lokalnego i najbardziej globalnego, wydaje się niewystarczające. Nie można traktować obrazu okresu życia jako prostej sumy zapamiętanych scen $\mathrm{z}$ tego czasu, toteż nie wiadomo, w jakim stopniu charakterystyka pojedynczych wspomnień dotyczy obrazu całości okresu życia. Jednocześnie obraz dzieciństwa może posiadać swoją specyfikę i wyróżniać się z całej autobiografii. 


\section{Zmiany rozwojowe pamięci dzieciństwa}

Przesłanki z obszaru badań nad pamięcią autobiograficzną i tożsamością narracyjną nie dają jednoznacznej odpowiedzi na pytanie o kierunek rozwoju pamięci dzieciństwa w biegu dorosłego życia (Jezierski, w druku) i dlatego potrzebne są badania empiryczne koncentrujące się właśnie na tym okresie. Zasadniczy problem dotyczy opracowania poznawczego pamięci dzieciństwa i związanej z tym dostępności wspomnień. Im człowiek jest starszy, tym dzieciństwo staje się coraz odleglejszym, ale też i proporcjonalnie krótszym fragmentem życia. Mimo zachodzących procesów zapominania (Wixted, 2004) i zyskiwania nowych istotnych doświadczeń w dorosłości dzieciństwo nie musi stawać się mniej dostępne w pamięci. Należy wziąć pod uwagę, że zapominanie jest procesem integrującym ślady pamięciowe, dzięki któremu pojedyncze wspomnienia włączane są w bardziej ogólne schematy autobiograficzne (Conway i in., 2004). Skoro funkcją pamięci jest tworzenie wiedzy autobiograficznej i obrazu ,ja" (Fivush, Nelson, 2004), to może się okazać, że mimo zmniejszania się szczegółowości i adekwatności zapamiętanych scen z dzieciństwa okres ten nadal jest ważną częścią autobiografii. Może takim pozostawać, gdyż w dorosłości jest regularnie przypominany w kontekście definiowania tego, kim się jest aktualnie. Badania nad krzywą zapominania pokazują, że wyraźnemu zatarciu ulegają głównie najświeższe wspomnienia, przez co w starości zachowana zostaje typowa dystrybucja wspomnień z poszczególnych lat życia ${ }^{1}$ (Janssen, Rubin, Jacques, 2011).

Koncepcje rozwoju człowieka w dorosłości rzucają nowe światło na analizowane zagadnienie. Mianowicie pokazują, że istotne doświadczenia życiowe mogą nie tylko wpisywać się w dotychczasowe struktury poznawcze ,ja" i wiedzy autobiograficznej, ale też, gdy nie pasują do posiadanych schematów, zmieniają perspektywę interpretacyjną wspomnień (Dryll, 2008). Oznacza to, że w obrębie wiedzy o sobie i swoim życiu oprócz asymilacji doświadczeń w posiadane schematy zachodzi także akomodacja struktur poznawczych. Rozwój narracyj- nego rozumienia siebie w obliczu ważnych doświadczeń i zmieniającej się sytuacji życiowej może skłaniać do coraz lepszego opracowania poznawczego własnej przeszłości, przez co pamiętane dzieciństwo być może nawet zyskiwałoby na znaczeniu we wciąż uaktualnianej historii życia.

Szczególnym bodźcem do zmiany rozumienia swojej przeszłości są typowe zadania rozwojowe. Przykładowo Dan McAdams wraz ze współpracownikami (McAdams, Diamond, de St. Aubin, Mansfield, 1997) wykazali, że w średniej dorosłości osoby, które wykazują się wysoką generatywnością ${ }^{2}$, tworzą historie życia uporządkowane wokół zaangażowania na rzecz innych. Opowiadania te są tak konstruowane, że trudne sytuacje i wydarzenia $\mathrm{z}$ dzieciństwa stają się źródłem aktualnego zaangażowania w działania dla dobra przyszłych pokoleń. Według Piotra Olesia (2000) w średniej dorosłości pojawia się okazja do ewaluacji dotychczasowej drogi życiowej i świadomych korekt kierunku rozwoju. Kolejny raz podsumowanie staje się szczególnie istotne w późnej dorosłości w obliczu antycypowanego końca życia (Erikson, 1954/ 2004; Oleś, 2000). Pozytywny rozwój W starości polega na odnalezieniu sensu i celu życia, akceptacji swojej przeszłości, teraźniejszości oraz przyszłości, a więc nieuchronnej perspektywy śmierci (Kałużna-Wielobób, 2014). Wraz z wiekiem zmienia się perspektywa temporalna - zwiększa się stosunek ilości czasu przeżytego do przewidywanej długości życia, co może powodować, że przeszłość staje się coraz ważniejsza (Draaisma, 2012).

Zarówno zmiana w sytuacji życiowej związana $\mathrm{z}$ typowymi zadaniami rozwojowymi w dorosłości, jak i nienormatywne przełomowe momenty skłaniają do poddania przeżytego życia ewaluacji. Zastanawiające jest, czy w tych sytuacjach również dzieciństwo jest rewidowane i czy dzięki temu jest lepiej rozumiane oraz w większym niż do tej pory stopniu przemyślane. Zmianie perspektywy spojrzenia na własne dzieciństwo sprzyjać mogą także poszerzające się w dorosłości możliwości poznania i rozumienia siebie. W koncepcji myślenia postformalnego Giselle Labouvie-Vief (2005) zmiany rozwojowe w dorosłości idą w kierunku budo- 
wania bardziej kompleksowego i bogatszego obrazu ,ja", pozwalającego na integrowanie szerszej gamy doświadczeń. Zatem perspektywa rozwoju skłania do wysunięcia hipotezy, że wraz z pogłębiającą się z wiekiem refleksją nad własnym życiem dzieciństwo staje się coraz bardziej przemyślaną i łatwiej dostępną częścią autobiografii.

\section{Problem struktury pamięci okresu dzieciństwa}

Dotychczasowe rozważania w nurcie psychologii narracyjnej skupiały się na wykrywaniu treści nadających spójność indywidualnym historiom życia i ich związku z rozwojem w dorosłości (np. Baddeley, Singer, 2007; Zaman, Fivush, 2013), natomiast brakuje badań pokazujących, jak zmienia się stopień tej spójności w spontanicznie produkowanych wspomnieniach. Być może wynika to z założenia, że skoro $\mathrm{w}$ adolescencji poznawcza zdolność do budowania globalnej koherencji historii życia została już osiągnięta, to również wszystkie subiektywnie znaczące doświadczenia organizowane są w sposób spójny. Jednak należy uwzględnić też fakt, że włączanie nowych scen życia w całościowy spójny wzorzec opowiadania jest procesem zachodzącym w czasie i wymagającym świadomego wysiłku, stąd można założyć, że osiąganie spójności narracji o życiu przebiega stopniowo i być może nigdy nie jest zakończone.

Zaprezentowane rozważania teoretyczne skłoniły do poruszenia problemu dotyczącego rozwojowej specyfiki formalnego aspektu pamięci okresu dzieciństwa. $\mathrm{Na}$ ich podstawie poczyniono poniższe założenia.

1. Pamięć dzieciństwa jest reprezentowana w umyśle dorosłej osoby jako całościowy okres, który posiada swoje unikatowe charakterystyki.

2. Pamięć dzieciństwa jest częścią hierarchicznej struktury, na którą składają się: na poziomie lokalnym pojedyncze wspomnienia, a na najbardziej globalnym - schemat historii życia. Zatem dzieciństwo jest reprezentowane na poziomie pośrednim, przez co wpisuje się w schemat historii życia i organizuje pojedyncze wspomnienia.

3. Człowiek dąży do zachowania wewnętrznej spójności autobiografii w obrębie całej historii życia i wchodzących w jego skład okresów. Istotne doświadczenia w dorosłości oraz zmiana sytuacji życiowej mogą prowadzić do adaptacji schematu całej autobiografii i tym samym do zmiany sposobu spostrzegania własnego dzieciństwa.

4. Począwszy od końca adolescencji, człowiek wielokrotnie rewiduje swoją biografię, przez co dzieciństwo wciąż poddawane jest refleksji, a jego wizja ewoluuje.

5. Refleksja nad autobiografią staje się częstsza w kolejnych okresach rozwojowych, przez co pamięć dzieciństwa staje się bardziej dostępna.

6. Powtarzająca się refleksja nad własnym dzieciństwem prowadzi do większej spójności jego wizji w późniejszych okresach rozwojowych dorosłości.

W związku z wymienionymi założeniami postawiono pytanie: czy pamięć dzieciństwa jest bardziej spójna i dostępna w późniejszych okresach rozwojowych? Za przejaw dostępności wspomnień uznano objętość wypowiedzi. Operacjonalizując spójność obrazu dzieciństwa, posłużono się pojęciem globalnej koherencji historii życia (Habermas, Bluck, 2000), uwzględniono temporalny oraz przyczynowy i tematyczny wymiar tej koherencji. Za przejaw koherencji temporalnej uznano umiejscowienie wspomnień na osi czasu, a koherencji przyczynowej i tematycznej - liczbę relacji przyczynowych i tematycznych między poszczególnymi wspomnieniami.

\section{Hipotezy}

Narracyjna reprezentacja własnego dzieciństwa osób w kolejnych okresach rozwojowych dorosłości (wczesnej, średniej i późnej) jest:

1. bardziej rozbudowana,

2. w większym stopniu umiejscowiona na osi czasu,

3. bardziej spójna tematycznie i przyczynowo. 
Tabela 1. Osoby badane - charakterystyka grup wiekowych

\begin{tabular}{|l|l|c|c|c|c|}
\hline & \multicolumn{1}{|c|}{ Okres rozwojowy } & Przedział wieku & $\boldsymbol{n}$ & $\boldsymbol{M}$ & $\boldsymbol{S D}$ \\
\hline Grupa 1 & Wczesna dorosłość & $25-36$ lat & 20 & 30.1 & 2.7 \\
\hline Grupa 2 & Średnia dorosłość & $45-55$ lat & 20 & 48.6 & 4.7 \\
\hline Grupa 3 & Późna dorosłość & $65-80$ lat & 20 & 71.4 & 5.7 \\
\hline
\end{tabular}

\section{METODA}

\section{Osoby badane}

W badaniu brało udział w sumie 60 osób, które dobrano tak, aby znajdowały się w trzech grupach wiekowych: wczesnej, średniej i późnej dorosłości; informacje liczbowe o osobach badanych znajdują się w tabeli 1 . Osoby w najmłodszej i środkowej grupie miały wykształcenie wyższe, ich głównym zajęciem była praca zawodowa, ewentualnie zajmowanie się dziećmi. Osoby z najstarszej grupy miały wykształcenie średnie lub wyższe i nie pracowały ani nie opiekowały się innymi członkami rodziny.

\section{Wywiad narracyjny}

Procedura. W przeprowadzonym badaniu posłużono się autorskim wywiadem narracyjnym, który miał umożliwić spontaniczne ujawnienie się sposobu organizacji wiedzy autobiograficznej. Ponadto uznano, że takie narzędzie jest właściwe we wstępnym etapie eksplorowania zagadnienia. Wywiad przeprowadzany był ustnie. W pierwszej części, chcąc uzyskać swobodną wypowiedź na temat całego dzieciństwa, pytano: ,proszę przypomnieć sobie swoje dzieciństwo, proszę opowiedzieć mi o nim”. W drugiej części podawano instrukcje, które miały skłonić do pogłębienia refleksji nad dzieciństwem. Najpierw dawano polecenia mające stymulować przywołanie konkretnych wspomnień: proszono o opis zapamiętanego przedmiotu i wybranego wspomnienia, następnie przechodzono do pytań odnoszących się do refleksji nad całością okresu życia, a mianowicie pytano o początek i koniec dzieciństwa oraz o wpływ dzieciństwa na późniejsze życie oraz o zmianę sposobu postrzegania dziecięcych wspomnień.

Analiza. Dosłownie spisany wywiad analizowało dwóch sędziów kompetentnych, którzy najpierw pracowali osobno, a potem uzgadniali swoje odpowiedzi aż do osiągnięcia konsensusu; w przypadku braku zgody rozstrzygający głos miał trzeci sędzia. Właściwe analizy poprzedzał podział tekstu na jednostki, które miały odpowiadać pojedynczym wspomnieniom. Jednostki te (dalej określane ,wspomnieniami”) wyróżniano, posługując się definicją epizodu³. Tak przygotowaną wypowiedź analizowano pod kątem wskaźników wynikających z postawionych hipotez ${ }^{4}$. Tabela 2 przedstawia listę wskaźników użytych do analiz. Rozbudowanie wypowiedzi (ad hipoteza 1) określały dwa wskaźniki: (a) liczby słów i (b) liczby przywoływanych wspomnień. W tym przypadku wynik stanowił prostą sumę wszystkich słów albo wspomnień wchodzących w skład wypowiedzi o dzieciństwie (wykluczono wypowiedzi nieodnoszące się do tematu dzieciństwa). Wskaźnik (c) umiejscowienia w czasie (ad hipoteza 2) wyrażał liczbę wspomnień, w których określono datę opisywanej sytuacji, odniesiono ją do innej sytuacji (przed/w trakcie/po). Wskaźnik (d) relacji logicznych (hipoteza 3) definiowany był natomiast jako liczba wspomnień, które odnosiły się w sposób sensowny do innych wspomnień na zasadzie relacji przyczynowej lub wspólnego głównego tematu. Wskaźniki c i d obliczano w taki sposób, że sprawdzano każde wspomnienie po kolei, by ustalić, czy 
Tabela 2. Wskaźniki służące do analizy wywiadu

\begin{tabular}{|c|l|l|l|}
\hline Nr hipotezy & Kierunki analizy & \multicolumn{1}{|c|}{ Wskaźniki } & \multicolumn{1}{|c|}{ Wynik } \\
\hline 1 & \multirow{2}{*}{ Rozbudowanie } & (a) liczba słów & Suma \\
\cline { 3 - 4 } & (b) liczba wspomnień & Suma \\
\hline 2 & $\begin{array}{l}\text { Globalna } \\
\text { koherencja }\end{array}$ & $\begin{array}{l}\text { (c) umiejscowienie wspomnień } \\
\text { w czasie }\end{array}$ & $\begin{array}{l}\text { Suma, proporcja do } \\
\text { rozbudowania }\end{array}$ \\
\cline { 3 - 4 } & $\begin{array}{l}\text { (d) logiczne relacje pomiędzy } \\
\text { wspomnieniami (przyczynowe } \\
\text { i tematyczne) }\end{array}$ & $\begin{array}{l}\text { Suma, proporcja do } \\
\text { rozbudowania }\end{array}$ \\
\hline \multirow{2}{*}{3} & &
\end{tabular}

spełnia odpowiednie kryterium. Równocześnie w odróżnieniu od wskaźników rozbudowania wypowiedzi (a i b) liczono dwa rodzaje wyników: zarówno prostą sumę wspomnień spełniających analizowane kryterium, jak i sumę wspomnień spełniających kryterium w proporcji do wszystkich wspomnień w narracji.

\section{WYNIKI}

\section{Rozbudowanie wypowiedzi}

Tabela 3 ukazuje rozbudowanie wypowiedzi w poszczególnych grupach wiekowych. W grupie 1 wypowiedzi składały się średnio z 2188 słów (mediana: 2154), sędziowie wyodrębnili średnio 21,2 wspomnienia (mediana 19,5). W grupie 3 opowiadania były niemal dwukrotnie dłuższe i zawierały średnio 4229 słów (mediana 3856) i 35,9 wspomnienia (mediana 37,0). Grupa 2 (środkowa dorosłość) nie różniła się znacząco od pozostałych, średnie wskaźniki objętości plasowały się pomiędzy młodszą i starszą grupą, przyjmując wielkość 3929 słów i 30 wspomnień. Analizy testem Anova rang Kruskala-Wallisa ${ }^{5}$ wykazały istotne statystycznie różnice między grupami wiekowymi w rozbudowaniu wypowiedzi (tabela 4). Związek ten ujawnił się zarówno w przypadku najprostszego wskaźnika rozbudowania, czyli liczby słów, jak i bardziej zaawansowanego - liczby wspomnień. Testy post-hoc (zawarte w tabeli 5) pokazały, że istotne różnice wystąpi- ły między grupą 1 (wczesnej dorosłości) i grupą 3 (późnej dorosłości). Zatem, ogólnie rzecz ujmując, narracje osób z najstarszej badanej grupy wiekowej - późnej dorosłości - były bardziej rozbudowane niż narracje osób z pozostałych dwóch grup wczesnej i średniej dorosłości.

\section{Globalna koherencja wypowiedzi}

Umiejscowienie wspomnień w czasie. Niecała jedna trzecia wspomnień była umiejscowiona na osi czasu, o czym świadczy wskaźnik liczby wspomnień posiadających odniesienia temporalne w proporcji do liczby wszystkich wspomnień, który przyjął średnią wielkość .28. W poszczególnych grupach wiekowych współczynnik ten był zbliżony; wyniósł on we wczesnej dorosłości .26, w środkowej .32, w późnej .26 (tabela 6). Jednoczynnikowa analiza wariancji ANOVA ${ }^{6}$ nie wykazała różnic między nimi (tabela 7). Podobnie zbliżona w kolejnych grupach wiekowych była prosta suma wspomnień umiejscowionych w czasie, średnio w jednym wywiadzie było ich w kolejnych grupach: 5.9, 10.8 i 11.8 (tabela 6).

Relacje logiczne. Narracje tworzone przez osoby z najstarszej grupy wiekowej zawierały więcej wspomnień powiązanych logicznie (tj. tematycznie i przyczynowo). Jak pokazuje tabela 7, analiza wariancji ANOVA ujawniła istotne różnice między grupą wiekową a liczbą powiązanych logicznie wspomnień w wypowiedzi $\left(F_{(2.57)}=6.72 ; p<.01\right)$. W grupie wczesnej dorosłości znajdowało się średnio 8.2 wspo- 
Tabela 3. Rozbudowanie wypowiedzi. Statystyki opisowe: średnia i odchylenie standardowe

\begin{tabular}{|l|l|l|l|l|l|l|}
\hline & \multicolumn{3}{|c|}{ Liczba słów } & \multicolumn{3}{c|}{ Liczba wspomnień } \\
\hline Grupa wiekowa & $M$ & $M d$ & $S D$ & $M$ & $M d$ & $S D$ \\
\hline 1) wczesna dorosłość & 2188 & 2154 & 1017 & 21.2 & 19.5 & 10.7 \\
\hline 2) średnia dorosłość & 3929 & 2718 & 3251 & 30.0 & 26.0 & 22.3 \\
\hline 3) późna dorosłość & 4229 & 3856 & 2034 & 35.9 & 37.0 & 16.7 \\
\hline Całość próby & 3449 & 2909 & 2101 & 29.0 & 27.5 & 16.6 \\
\hline
\end{tabular}

Tabela 4. Różnice między grupami wiekowymi w rozbudowaniu wypowiedzi. Wyniki analizy testem Anova rang Kruskala-Wallisa

\begin{tabular}{|l|c|c|c|}
\hline \multicolumn{1}{|c|}{ Efekt grupy wiekowej dla: } & $\boldsymbol{H}$ & $\boldsymbol{d f}$ & $\boldsymbol{p}$ \\
\hline Liczba słów & 12.38 & 2 & $<.05$ \\
\hline Liczba wspomnień & 8.79 & 2 & $=.01$ \\
\hline
\end{tabular}

Tabela 5. Różnice między grupami wiekowymi w rozbudowaniu wypowiedzi. Wyniki testów post-hoc

\begin{tabular}{|l|l|l|l|}
\hline & gr. 1 vs gr. 2 & gr. 2 vs gr. 3 & gr. 1 vs gr. 3 \\
\hline Liczba słów & n.i. & n.i. & $<.05$ \\
\hline Liczba wspomnień & n.i. & n.i. & $=.01$ \\
\hline
\end{tabular}

mnień nawiązujących do innych, w grupie średniej dorosłości 14.6, a w późnej 16.6. Test post-hoc NIR ujawnił istotne różnice między wczesną i średnią dorosłością $(p=.01)$ oraz między wczesną i późną dorosłością $(p<.001)$, co pokazuje, że - podobnie jak w przypadku objętości wypowiedzi - najwyraźniejsza różnica była między najmłodszą i najstarszą grupą badanych (tabela 8). Nie zauważono natomiast różnic między grupami wiekowymi, gdy wskaźnik spójności był wyrażony jako proporcja licz- by wspomnień powiązanych logicznie do liczby wszystkich wspomnień w wywiadzie (pokazywał on, jaka część wypowiedzi była spójna, niezależnie od jej objętości). Średnia tegoż wskaźnika proporcji była nieznacznie niższa w grupie wczesnej dorosłości, w której wyniosła średnio .39, od pozostałych obu grup, w których miały taką samą wartość .48. Analiza wariancji ANOVA nie wykazała tu różnic między grupami $\left(F_{(2.57)}=1.11 ; p>.05\right)$. Powyższe wyniki oznaczają, że osoby w średniej i w późnej do- 
Tabela 6. Statystyki opisowe: średnia i odchylenie standardowe wskaźnika umiejscowienia wspomnień w czasie

\begin{tabular}{|c|c|c|c|c|c|c|}
\hline \multirow[b]{3}{*}{ Grupa wiekowa } & \multicolumn{6}{|c|}{ Umiejscowienie wspomnień w czasie } \\
\hline & \multicolumn{3}{|c|}{ Suma w wywiadzie } & \multicolumn{3}{|c|}{ Proporcja do objętości wywiadu } \\
\hline & $M$ & $M d$ & $S D$ & $M$ & $M d$ & $S D$ \\
\hline 1) wczesna dorosłość & 5.8 & 5.0 & 4.0 & .26 & .23 & .15 \\
\hline 2) średnia dorosłość & 11.4 & 9.0 & 12.1 & .32 & .34 & .13 \\
\hline 3) późna dorosłość & 12.3 & 9.5 & 8.3 & .26 & .26 & .13 \\
\hline \multirow[t]{3}{*}{ Całość próby } & 9.8 & 7.8 & 8.1 & .28 & .28 & .14 \\
\hline & \multicolumn{6}{|c|}{ Relacje logiczne } \\
\hline & \multicolumn{3}{|c|}{ Suma w wywiadzie } & \multicolumn{3}{|c|}{ Proporcja do objętości wywiadu } \\
\hline Grupa wiekowa & $M$ & $M d$ & $S D$ & $M$ & $M d$ & $S D$ \\
\hline 1) wczesna dorosłość & 8.2 & 6.0 & 6.1 & .39 & .34 & .28 \\
\hline 2) średnia dorosłość & 14.3 & 12.0 & 9.4 & .48 & .49 & .24 \\
\hline 3) późna dorosłość & 16.6 & 18.0 & 6.7 & .48 & .49 & .18 \\
\hline Całość próby & 13.0 & 12.0 & 8.2 & .45 & .44 & .24 \\
\hline
\end{tabular}

rosłości w porównaniu z młodymi dorosłymi przywoływały więcej wspomnień odnoszących się do siebie wzajemnie i tworzących logicznie spójną narrację. Należy jednak zaznaczyć, że te spójniejsze wypowiedzi w starszych grupach wiekowych były także bardziej rozbudowane, czyli zawierały więcej wspomnień niespójnych, a tym samym we wszystkich grupach wiekowych zbliżona część wypowiedzi była ze sobą powiązana.

Średnia wskaźnika proporcji dla wszystkich osób badanych była na poziomie 0.45 , co oznacza, że przeciętnie niemal połowa wypowiedzi została uznana przez sędziów za logicznie spójną, a pozostała część tekstu składała się z osobnych, niepowiązanych ze sobą wspomnień.

\section{DYSKUSJA}

Przeprowadzone badania narracyjne miały odpowiedzieć na pytanie, czy dorośli znajdujący się w późniejszych okresach rozwojowych inaczej pamiętają dzieciństwo. Na podstawie analiz teoretycznych wysunięto przypuszczenie, że pamięć dzieciństwa jest bardziej dostępna i lepiej opracowana poznawczo w późniejszych okresach rozwojowych, przy czym za wyraz dostępności uznano obszerność wypowiedzi, a za przejaw opracowania poznawczego wybrane wskaźniki globalnej koherencji wypowiedzi: ułożenie temporalne oraz logiczne. Założono, że dzięki rozbudzanej sytuacją życiową i zadaniami rozwojowymi refleksji nad własną bio- 
Tabela 7. Globalna koherencja narracji. Wyniki testu jednoczynnikowej analizy wariancji (ANOVA)

\begin{tabular}{|l|c|c|c|}
\hline \multicolumn{1}{|c|}{ Efekt grupy wiekowej dla: } & Wynik testu & $d f$ & $\boldsymbol{p}$ \\
\hline Wspomnienia umiejscowione w czasie: & & 2 & $p=.06$ \\
\hline - suma w wywiadzie & $F_{(2,57)}=3.02$ & 2 & n.i. \\
\hline - w proporcji do objętości wywiadu & $F_{(2,57)}=.74$ & 2 & $p<.01$ \\
\hline Relacje logiczne między wspomnieniami: & & $F_{(2,57)}=6.72$ & n.i. \\
\hline - suma w wywiadzie & $F_{(2,57)}=1.11$ & 2 & \\
\hline - w proporcji do objętości wywiadu & & & \\
\hline
\end{tabular}

Tabela 8. Różnice między grupami wiekowymi we wskaźnikach globalnej spójności. Wyniki testu post-hoc NIR

\begin{tabular}{|l|l|l|}
\hline gr. 1 vs gr. 2 & gr. 2 vs gr. 3 & gr. 1 vs gr. 3 \\
\hline \multicolumn{3}{|c|}{ Suma wspomnień umiejscowionych w czasie } \\
\hline n.i. $(p=.07)$ & n.i. & $p<.05$ \\
\hline \multicolumn{3}{|c|}{ Suma relacji logicznych między wspomnieniami } \\
\hline$p=.01$ & n.i. & $p<.001$ \\
\hline
\end{tabular}

grafią dziecięce wspomnienia są częściej przywoływane oraz układają się w bardziej spójny obraz.

\section{Specyfika rozwojowa pamięci dzieciństwa}

Otrzymane wyniki pozostają po części w zgodzie z przewidywaniami. Obraz dzieciństwa, który ujawnił się w swobodnych wypowiedziach osób dorosłych, wykazał specyfikę związaną z okresem rozwojowym najwyraźniejszą we wczesnej i późnej dorosłości. Mianowicie w najstarszej grupie w porównaniu z najmłodszą budowano obszerniejsze opowiadania o dzieciństwie, ale też więcej wspomnień łączyło się ze sobą tematycznie i przyczynowo. Zaobserwo- wane w przeprowadzonych badaniach związane $\mathrm{z}$ wiekiem różnice w sposobie opowiadania o dzieciństwie wydają się wspierać tezę, że w starości okres ten staje się szczególnie istotną częścią osobistej historii. Teoria rozwoju psychospołecznego E.H. Eriksona (1954/2004) zakłada, że w starości człowiek staje przed koniecznością przeprowadzenia bilansu przeżytego życia, co z pewnością skłania do przemyśliwania swojej historii, w tym i dzieciństwa.

Rozbudowanie i spójność logiczna wypowiedzi osób badanych znajdujących się w okresie średniej dorosłości plasowały się zwykle pomiędzy młodymi i starszymi dorosłymi, mimo tego nie wykazano istotnie statystycznej różnicy wobec pozostałych grup. Brak sta- 
tystycznych różnic między okresem średniej dorosłości a pozostałymi można wiązać z większą heterogenicznością wyników w tej grupie oraz z niewielką liczbą osób badanych. Wysokie zróżnicowanie rozbudowania wypowiedzi w grupie drugiej może odzwierciedlać dużą różnorodność podejmowanej refleksyjności nad życiem w średniej dorosłości. Piotr Oleś (2000) twierdzi, że właśnie w średniej dorosłości ujawnia się potrzeba rewizji kierunku własnego życia, jednak - w przeciwieństwie do późnej dorosłości - podjęcie refleksji nie jest jeszcze koniecznością. Istnieją zróżnicowane ścieżki przechodzenia przez ten przełomowy czas i poza świadomą przebudową wizji siebie oraz swojego życia możliwa jest też impulsywna zmiana w otoczeniu lub pozostanie w dotychczasowych schematach zachowań. Zróżnicowanie sposobów konfrontacji z ,przełomem połowy życia” mogło powodować, że dla niektórych osób w średniej dorosłości prośba o opowiedzenie o swoim dzieciństwie mogła być oderwanym od codzienności niezbyt istotnym zadaniem, zaś dla innych okazją do ujawnienia już podjętej refleksji nad ich życiem.

Opowiadania o dzieciństwie osób dorosłych były wbrew przewidywaniom w podobnym stopniu umiejscowione w czasie niezależnie od okresu rozwojowego badanych. Warto zaznaczyć, że wyniki wskaźnika spójności temporalnej układały się w próbie inaczej niż pozostałych wskaźników, a mianowicie ich rozkład był normalny, a zróżnicowanie raczej umiarkowane. Przytoczony we wprowadzeniu model rozwoju globalnej spójności autobiografii (Habermas, Bluck, 2000) zakłada, że umiejętność temporalnego ułożenia wspomnień z przeszłości w wymiarze całego życia jest elementem przyswajanego w kulturze modelu biografii, który staje się bazą dla pojawiającej się później spójności tematycznej i przyczynowej. Christin Köber ze współpracownikami (Köber, Schmiedek, Habermas, 2015) zaobserwowała, że częstość stosowania wskaźników czasowego ułożenia wspomnień wzrastała w adolescencji i pozostawała stabilna w dorosłości. Zatem być może temporalne ułożenie wspomnień z dzieciństwa stanowi wyraz konwencjonalnej struktury, nie- koniecznie zależnej od pogłębiającej się z wiekiem refleksji nad swoim życiem.

\section{Obraz dzieciństwa wylaniający się z badań}

W niniejszym artykule skupiano się na specyfice postrzegania dzieciństwa związanej z okresem rozwojowym, jednak na podstawie przeprowadzonych wywiadów można też podjąć próbę opisania ogólnego obrazu pamięci tego okresu u osób dorosłych. W świetle analizowanych koncepcji zaskakujące było, że swobodne opowiadania o dzieciństwie charakteryzowała umiarkowana spójność na poziomie globalnym w każdym z badanych wymiarów. Uszczegóławiając, w wypowiedziach osób badanych w każdym z okresów rozwojowych ponad dwie trzecie wspomnień nie było w żadnym stopniu umiejscowione na osi czasu, a ponad połowa nie odnosiła się do siebie w sposób tematyczny ani przyczynowy. Zatem dzieciństwo wyłaniające się z zebranych wypowiedzi składało się w większości z osobnych scen, nienawiązujących do siebie i ,zawieszonych” w czasie. Zakładając na podstawie koncepcji tożsamości narracyjnej, że podstawową funkcją pamięci autobiograficznej jest budowanie poczucia ciągłości w wymiarze całego życia przejawiającej się globalną spójnością autobiografii (Jezierski, 2010; McAdams, McLean, 2013), interpretacja otrzymanego obrazu dzieciństwa sprawia istotną trudność. Oczywiście opisane badania, między innymi ze względu na liczność próby, powinny służyć jedynie do stawiania hipotez, a nie wysuwania pewnych wniosków, jednak jeżeli zostałyby potwierdzone, wskazywałyby na istotne ograniczenia przytaczanego ujęcia tożsamości narracyjnej.

Wydaje się, że można wykluczyć wyjaśnienia umiarkowanej lub niskiej globalnej koherencji wspomnień odnoszące się do ograniczonych możliwości poznawczych lub niskiej motywacji. Osoby badane miały w większości wykształcenie wyższe (w niektórych przypadkach średnie), więc można zakładać, że posiadały umiejętność myślenia na poziomie formalnym, a tym samym były zdolne do budowania koherentnej historii życia (Habermas, de Silveira, 2008). Wskaźniki objętości wypowiedzi suge- 
rują natomiast, że badani chętnie przywoływali osobiste doświadczenia i podejmowali wysiłek ich spójnego opisu w ramach wewnętrznie sensownych wspomnień. Wobec tego nasuwa się przypuszczenie, że większość łatwo dostępnych wspomnień $z$ dzieciństwa nie jest traktowana przez osoby badane jako składowa przemyślanego schematu historii życia.

Tożsamość może wyrażać się także w inny sposób niż ułożenie poszczególnych wspomnień w większą historię. Można opowiadać o różnorodnych wspomnieniach ze swojej autobiografii, które były szczególnie znaczące z powodów emocjonalnych, takich jak relacja z ważną osobą czy istotne zaangażowanie, a jednocześnie nie tworzyły przemyślanej logicznie historii. Wydaje się, że doświadczenia, które są łatwo dostępne w pamięci, nadal mogą definiować osobę, pokazując to, co jest kluczowe w jej autobiografii, a niekoniecznie wpisując się $\mathrm{w}$ jednolite opowiadanie.

\section{Wnioski do dalszych badań}

Istotne ograniczenie przeprowadzonych badań wynika z przyjętego rozumienia spójności obrazu dzieciństwa i jego operacjonalizacji. Nawiązuje ono wprost do pojęcia globalnej koherencji narracji, która definiowana jest przez autorów koncepcji tożsamości narracyjnej jako odnoszenie się do siebie części autobiografii i tworzenie sensownej całości w postaci historii życia (Habermas, Bluck, 2000; McAdams, 2001). Takie jej definiowanie może prowadzić do zbytnich uproszczeń i uznawania za wzór koherentnej narracji klasycznego dziewiętnastowiecznego wzorca opowiadania, linearnie uporządkowanego wokół głównego wyeksplikowanego wątku. W prowadzonych badaniach analizowano jedynie przejawy koherencji ujęte w sposób najprostszy jako liczba odnoszących się do siebie wspomnień. Z pewnością taki sposób pomiaru ignoruje mniej oczywiste i bardziej wysublimowane sposoby tworzenia sensownej narracji.

Zaprezentowane w artykule ujęcie problemu uporządkowania pamięci okresu dzieciństwa jest względnie nowe, dlatego otrzymane wyniki należy traktować jako przyczynek do dalszych poszukiwań, a ich główna wartość polega na wyznaczaniu kierunku hipotez do weryfikacji. Należałoby potwierdzić otrzymane związki na większej próbie oraz zweryfikować wysunięte na ich podstawie wnioski w inaczej zaprojektowanych badaniach. $Z$ pewnością dalszej eksploracji wymaga teza mówiąca, że rozwój sposobu postrzegania dzieciństwa $\mathrm{w}$ dorosłości polega nie tylko na porządkowaniu doświadczeń, ale też na zmianie lub poszerzaniu ich rozumienia (por. Jezierski, w druku). Jakkolwiek może się wydawać oczywista, wychodzi ona poza obecnie powszechne uznawanie spójności jako celu rozwoju rozumienia siebie (McAdams, 2006). Refleksja nad życiem podejmowana jest w odpowiedzi na nowe doświadczenia, które moga być asymilowane w posiadane schematy, jakimi człowiek posługiwał się w rozumieniu swojego życia, ale też te schematy mogą ulegać akomodacji, przez co zmienia się perspektywa interpretacyjna wspomnień (Dryll, 2008). Tym samym nadawanie spójności doświadczeniom stanowi ciągły proces, który - jak można przypuszczać - w większości przypadków nie prowadzi do stworzenia gotowego i uporządkowanego wzorca dzieciństwa.

Warto też zauważyć, że dotychczasowe rozważania nad spójnością historii życia skupiały się w największym stopniu na okresie adolescencji i wkraczania w dorosłość (np. Syed, McLean, 2015). Skłania to do postawienia pytania, czy to właśnie wtedy stworzenie jednorodnej wizji życia jest kluczowe i rzeczywiście spójność opowiadanych historii życia stale się zwiększa. Być może warto byłoby na nowo poddać dyskusji zagadnienie globalnej koherencji historii życia i zastanowić się, czy rozwój w dorosłości nie idzie raczej w kierunku poszerzania perspektyw interpretacji własnej biografii i jej bogacenia niż narzucania spójnej struktury. Byłoby to zgodne z koncepcjami rozwoju myślenia postformalnego, które wskazują, że w dorosłości zwiększa się umiejętność odkrywania i formułowania problemów (Arlin, 1989), a przy ich rozważaniu uwzględniania sprzecznych perspektyw i znaczenia czynników społeczno-emocjonalnych (Michalska, Trempała, Szymanik-Kostrzewska, Gurba, 2016). 
W rozważaniach nad rozwojem wiedzy autobiograficznej wyjściem poza swego rodzaju dominację koherencji byłaby teza twierdząca, że funkcja tożsamościowa pamięci dzieciństwa nie jest najważniejsza w dorosłości, subiektywnie istotne wspomnienia są swego rodzaju „enklawą" minionych emocjonalnych doświadczeń, do których powraca się dla przyjemności lub przywołania bliskich relacji. Nie można też wykluczyć, że wspomnienia z dzieciństwa odbijają charakterystyczny dla dziecka sposób postrzegania świata, dlatego być może nie są one uporządkowane w globalny wzorzec, gdyż dziecko w ten sposób nie porządkuje, ale pozostają jedynie osobnymi scenami. Tutaj pojawia się też bardziej ogólny problem związku między schematem historii życia a reprezentacją dzieciństwa. W zaprezentowanych rozważaniach przyjmowano, że obecne w literaturze przedmiotu ustalenia dotyczące sposobu postrzegania autobiografii dotyczą także okresów życia, jednak należy pamiętać, że zostały one ekstrapolowane $\mathrm{z}$ badań nad historiami życia i tożsamością narracyjną. Brakuje danych empirycznych pokazujących, że pamięć dzieciństwa odróżnia się od pozostałej autobiografii, stąd też nie można wykluczyć, że te z opisanych w niniejszym artykule wyników, które wykraczały poza przyjęte założenie, że globalna koherencja jest celem rozwoju autobiografii, wynikają z odróżniania się pamięci dzieciństwa od reszty historii życia.

\section{Wnioski}

Autorska technika wywiadu narracyjnego pozwoliła na ukazanie postrzegania okresu dzieciństwa jako całości i tym samym wykroczyła poza klasyczne badania pamięci autobiograficznej, polegające na przywoływaniu poszczególnych wspomnień. Otrzymane wyniki z jednej strony ukazują, że dzieciństwo staje się okresem coraz bardziej przemyślanym i dostępnym w pamięci, a z drugiej skłaniają do dyskusji z założeniem, że globalnie spójna opowieść stanowi wyraz dojrzałego rozumienia swojego życia. Dzieciństwo może stanowić element autobiografii dającej poczucie spójności i sensowności osobie mierzącej się z bieżącymi wyzwaniami rozwojowymi, ale może też być zbiorem wyjątkowych i odrębnych momentów z przeszłości, wolnych od problemów dorosłych ludzi. W biegu życia człowiek ponownie zwraca się do osobistych doświadczeń z dzieciństwa, za każdym razem odkrywając i współtworząc je na nowo.

\section{PRZYPISY}

1 W dalszej części artykułu opisano dokładniej dystrybucję wspomnień w czasie w kontekście efektu reminiscencji.

2 Chodzi o pojęcie opisane przez E.H. Eriksona (1954/2004).

3 Przy podziale kierowano się definicją epizodu jako części tekstu odnoszącej się do reakcji bohatera, takiej jak: działanie, myśli, emocje, motywy, zmiany postaw (Głowiński, Sławiński, 1998; por. też Bokus, 1991). Epizod zawierał opis sytuacji, tj. warunki, zdarzenie, zmianę sytuacji w świecie przedstawionym, na którą reakcja bohatera jest odpowiedzią. Opis mógł się odnosić do pojedynczej lub powtarzających się reakcji głównego bohatera albo do uogólnionych wydarzeń. W wyjątkowych przypadkach jako osobne wspomnienie potraktowano samodzielne i rozbudowane fragmenty opisu świata przedstawionego, ponieważ można je uznać za osobne wspomnienia.

$4 \mathrm{~W}$ niniejszym artykule opisano jedynie wybrane z przeprowadzonych analiz, pozostałe nie mieściły się w ramach tej pracy, część została opublikowana lub zaprezentowana w innym miejscu (np. Kielar-Turska, Jezierski, w druku).

5 Zastosowano tutaj nieparametryczny test statystyczny, gdyż rozkład wyników nie spełniał kryterium jednorodności wariancji i normalności rozkładu.

6 W przypadku wskaźników umiejscowienia w czasie i relacji logicznych rozkład wyników był zbliżony do normalnego, co pozwoliło zastosować analizę wariancji ANOVA. 


\section{BIBLIOGRAFIA}

Ariès P. (1995), Historia dzieciństwa: dziecko i rodzina w dawnych czasach. Gdańsk: Wydawnictwo Marabut.

Arlin P.K. (1989), Problem solving and problem finding in young artists and young scientists. Adult development, 1, 197-216.

Baddeley J., Singer J.A. (2007), Charting the Life Story's Path: Narrative Identity Across the Life Span. W: D.J. Clandinin (red.), Handbook of narrative inquiry: Mapping a methodology. Thousand Oaks, CA, US: Sage Publications, Inc.

Bartosz B. (2004), Ludzie chcą opowiedzieć swoją historię: konstruowanie rzeczywistości w narracji (przez pryzmat doświadczeń autobiograficznych). W: E. Dryll, A. Cierpka (red.), Narracja: koncepcje i badania psychologiczne. Warszawa: Wydawnictwo Instytutu Psychologii PAN.

Bluck S., Habermas T. (2001), Extending the Study of Autobiographical Memory: Thinking Back About Life Across the Life Span. Review of General Psychology, 5(2), 135-147.

Bokus B. (1991), Tworzenie opowiadań przez dzieci. O linii i polu narracji. Kielce: Energeia.

Bruner J. (1991), The narrative construction of reality. Critical inquiry,18(1), 1-21.

Conway M.A., Singer J.A., Tagini A. (2004), The Self and Autobiographical Memory: Correspondence and Coherence. Social Cognition, 22(5), 525-531.

Draaisma D. (2012), Księga zapominania. Warszawa: Wydawnictwo Aletheia.

Dryll E. (2008), Doświadczenia życiowe a narracja tożsamościowa osoby. Psychologia Rozwojowa, 13(1), 59-67.

Erikson E.H. (1954/2004), Tożsamość a cykl życia. Poznań: Wyd. Zysk i Spółka.

Fivush R. (2011), The development of autobiographical memory. Annual Review of Psychology, 62, 559-582.

Fivush R., Bauer P.J. (2010), The emergence of recollection: How we learn to recall ourselves in the past. The act of remembering: Toward an understanding of how we recall the past, 259-283.

Fivush R., Nelson K. (2004), The Emergence of Autobiographical Memory: A Social Cultural Developmental Theory. Psychological Review, 111(2), 486 -511.

Gabbard G.O. (2011), Dlugoterminowa psychoterapia psychodynamiczna. Wprowadzenie. Kraków: Wydawnictwo UJ.

Głowiński M., Sławiński J. (1998), Podręczny słownik terminów literackich. Wrocław: Zakład Narodowy im. Osslińskich.

Habermas T., Bluck S. (2000), Getting a life: The emergence of the life-story in adolescence. Psychological Bulletin, 126, 748-769.

Habermas, T., \& de Silveira, C. (2008), The development of global coherence in life narratives across adolescence: Temporal, causal, and thematic aspects. Developmental Psychology, 44, 707-721. doi: 10.1037/00121649.44.3.707.

Janssen S.M., Rubin D.C., Jacques P.L.S. (2011), The temporal distribution of autobiographical memory: changes in reliving and vividness over the life span do not explain the reminiscence bump. Memory \& Cognition, 39(1), 1-11.

Jezierski K. (2010), Zagadnienie tożsamości w ujęciach D.P. McAdamsa i E.H. Eriksona. Psychologia Rozwojowa, 15(4), 93-102.

Jezierski K. (w druku), Postrzeganie dzieciństwa w biegu dorosłego życia - refleksje teoretyczne. W: Narracja i Rozwój. Warszawa: Liberi Libri.

Kałużna-Wielobób A. (2014), Do individual wisdom concepts depend on value? Polish Psychological Bulletin, 45(2), 112-127.

Kehily M.J. (2008), An introduction to childhood studies. Maidenhead, UK: Open University Press.

Kessen W. (1979), The American child and other cultural inventions. American Psychologist, 34(10), 815-820.

Kielar-Turska M. (2000), Obraz dziecka i dzieciństwa. Wychowanie w Przedszkolu, 6, 347-348.

Kielar-Turska M., Jezierski K. (w druku), Wartość dzieciństwa w rozwoju człowieka w okresie starości. W: G. Habrajska, A. Barańska-Szmitko (red.). Teorie i praktyki komunikacji. Łódź: Wydawnictwo Uniwersytetu Łódzkiego.

Köber C., Schmiedek F., Habermas T. (2015), Characterizing lifespan development of three aspects of coherence in life narratives: A cohort-sequential study. Developmental Psychology, 51(2), 260-275. 
Koops W. (2003), Imaging Childhood. W: W. Koops, M. Zuckerman (red.), Beyond the Century of the Child. Philadelphia: University of Pennsylvania Press.

Labouvie-Vief G. (2005), Self-with-other representations and the organization of the self. Journal of Research in Personality, 39, 185-205.

Manczak E.M., Mangelsdorf S.C., McAdams D.P., Wong M.S., Schoppe-Sullivan S., Brown G.L. (2016), Autobiographical memories of childhood and sources of subjectivity in parents' perceptions of infant temperament. Infant Behavior and Development, 44, 77-85.

McAdams D.P. (2001), The Psychology of Life Stories. Review of General Psychology, 5(2), 100-122.

McAdams D.P. (2006), The problem of narrative coherence. Journal of constructivist psychology, 19(2), $109-125$.

McAdams D.P., Diamond A., de St. Aubin E., Mansfield E. (1997), Stories of commitment: The psychosocial construction of generative lives. Journal of Personality and Social Psychology, 72(3), 678-694.

McAdams D.P., McLean K.C. (2013), Narrative identity. Current directions in psychological science, 22(3), 233-238.

Michalska P., Trempała J., Szymanik-Kostrzewska A., Gurba E. (2016), Rozwój myślenia w dorosłości: o sposobach badania rozumowania postformalnego w codziennych sytuacjach. Psychologia Rozwojowa, 21(2), 55-71.

Oleś P. (2000), Psychologia przełomu życia. Lublin: Tow. Naukowe KUL.

Piaget J. (1926/2011), Jak sobie dziecko świat wyobraża. Warszawa: PWN.

Pietrasiński Z. (1988), Rozwój z perspektywy jego podmiotu. W: M. Tyszkowa (red.), Rozwój psychiczny człowieka w ciagu życia. Warszawa: PWN.

Staudinger U.M. (2001), Life reflection: A social-cognitive analysis of life review. Review of General Psychology, 5, 148-160.

Syed M., McLean K.C. (2015), The future of identity development research: Reflections, tensions, and challenges. W: K.C. McLean, M. Syed (red.), The Oxford handbook of identity development, 562-573. New York: Oxford University Press.

Szczepska-Pustkowska M. (2009), Kategoria dziecka i dzieciństwa w nowożytnej myśli pedagogicznej. W: D. Klaus-Stańska, M. Szczepska-Pustkowska (red.), Pedagogika wczesnoszkolna - dyskursy, problemy, rozwiazania. Warszawa: Wydawnictwa Akademickie i Profesjonalne.

Wixted J.T. (2004), The psychology and neuroscience of forgetting. Annual Review of Psychology, 55, 235-269.

Zaman W., Fivush R. (2013), Stories of parents and self: Relations to adolescent attachment. Developmental psychology, 49(11), 2047-2056. 